\title{
The National Literary Canon in the Field of Tension Between Aesthetic and Ideological Principles. The Estonian Case with Indications to the Comparative Perspectives
}

\author{
MARJA UNT
}

\begin{abstract}
The article is an attempt to outline some problems regarding the literary and non-literary factors which are at work in the formation of the canon. The central example used in this analysis is the interactions between aesthetic and ideological principles in the treatments of Estonian literature of the Soviet period. As this example shows, these principles intertwine on many levels - from interpretation of single texts to the factors constituting the understanding of literary history and the literary canon which makes the interactions of different principles a complicated sphere indicating the need for reviewing the national canons in the comparative context and especially for further comparative studies of the literatures that share a similar historical experience from the $20^{\text {th }}$ century.
\end{abstract}

Keywords: literary canon, literary history, Soviet era, comparative studies

DOI: http://dx.doi.org/10.12697/IL.2013.18.1.06

There are various principles which can, for example, determine the periodization of (national) literary history: as pointed out by Tiit Hennoste in his analyses of the various methods of periodization, the main method can be based on either 'literary' or 'non-literary' factors (general social and/or political circumstances etc.); these, in turn, have their own varieties (Hennoste 2003: 59). In the case of Estonian literary history these tendencies are often intertwined. These two dominants, however, can be observed not only in the periodization of literary history but also in many works that tend towards some kind of generalisation of a literary period or phenomenon, thus affecting the formation of the literary canon at the broadest level, from the ways of mapping literary history and conducting research to the ways literature and literary history is taught at schools. This article tries to outline some problems regarding the literary and non-literary factors which are at work in the formation of canon, namely 
The National Literary Canon in the Field of Tension Between Aesthetic and IdeologicalPrinciples

the interactions between aesthetic and ideological principles ${ }^{1}$ in the treatments of Estonian literature of the Soviet period.

In 2009 the $8^{\text {th }}$ international conference of EACL focused on literary histories and the relations between national and supranational literary canon; in the papers published in the 1st volume of the two-volume issue of Interlitteraria after the conference, the tension between big and small (also Eastern and Western) literatures, aesthetic and culturalist principle, as well as national and supranational perspective is addressed in many papers. These seemingly oppositional pairs of notions or principles do not overlap completely but are noticeably related to each other. In the paper titled The Trans-national Literary Canon and Shared Literary History between Supra-National and National Dimensions, Ideologies and Literariness Vanesa Matajc addresses the questions regarding the role of the aesthetic principle (or 'literariness'), ideologies, and national cultural experience in the formation of the literary canon, concluding that although the national cultural history can affect the formation of the canon through ideologies thus possibly reducing the literariness of it, most attempts to describe the supra-national canon which seems to set off from the aesthetic principle, are noticeably centred around the 'bigger' (or Western) literatures and can be questioned from the viewpoint of ('smaller') national literatures (Matajc 2010: 101-118). The trans-national literary canon, as Matajc describes it, should be able to transcend the boundaries these approaches prescribe by "taking into account the literary/linguistic/cultural diversity and at the same time the complexity of the literary past", concentrating on the "literariness" as the dominant, but also considering the national literary canons in order to embrace this complexity (Matajc 2010: 119-120). To illustrate the different principles at work in the different means of canon formation, Matajc uses three examples: the fate of Slovenian poet France Balantič between two ideologies which for a long time neglected the literary 'autonomy' of his works; Harold Bloom's Western Canon (1994) which, stating to be relying on the "pure" aesthetic principle, is still questionable for the gaps in the repository of texts, and the most common treatments of Romanticism in which the 'smaller' nations are either absent or at least in the periphery (Matajc 2010: 101-118). The following is an attempt to offer another example of the tensions between the ideological and/

1 In the following analyses the notions "ideological" and "national" are in parallel use. The terms "national literature" or "national literary canon" do not necessarily indicate an ideological dimension, they can be considered as simply referring to the literary history or canon of one nation, most often determined by its shared linguistic and cultural experience. In the case of the Estonian literature of the Soviet period, however, the connotations of "national" are more or less ideological in most contexts. 
or national and the aesthetic dimension of the literary canon, a description of how these principles have been intertwined in the treatments of the Estonian literature of the Soviet time. ${ }^{2}$

As the necessary background of this example, it must be stressed that every attempt to observe the formation of the Estonian literary canon of the second half of the $20^{\text {th }}$ century is strongly affected by the fact that both literature and its reception during the Soviet period were subject to the censorship and the ideological pressure of the totalitarian regime. Therefore, trying to analyse the reception of the works of this time, it must be taken into consideration that the treatments of literature during the Soviet era can be considered only to a certain extent. It is thus obvious that the works about this literary period written during the past decades should be more reliable sources. There are, however, factors that also affect the retrospective approaches to the period. Estonian literature - and in one way or another presumably most literatures of the Eastern Bloc - of the Soviet period and its reception remain in an ambivalent space: it is a multilayered cultural situation in which the unofficial/not public layer either contradicts or complements (depending on the sub-period) the official culture. The era of the underground culture and underground magazines which began at the end of the 1960s and continued throughout the following decades is one of the clearest illustrations of this multilayered character of the culture of this period. In addition to the magazines and some other manuscripts (manuscript poetry and essay collections) distributed underground, this ambivalence of the cultural situation also affected the way of reading and interpreting texts, the way people perceived the canon in the broadest sense of it. Obviously, every literary study involves a certain amount of subjectivity, but in the case of the Soviet period, it appears that because of this partly public and partly non-public literary process, the personal or generational literary experience plays an essential role in the later treatments of this literary period, being quite often even stressed by the authors themselves.

The complexity of the cultural processes of the Soviet period has also led many researchers and literary historians to look for some kind of common

2 The Soviet period, quite naturally, cannot be viewed as a literary, cultural, or even political whole; depending on the principles, it can be divided into subperiods in one or another way, but it is clear that the Khrushchev 'thaw' represents the most obvious breaking-point. In the present treatment some phenomena are characteristic - to a smaller or greater extent - of the whole Soviet era, the main focus is, however, on the period following the 'thaw' and, although most of the observations apply to the whole literary canon, the questions of the canon of the Soviet time more often revolve around poetry. 
The National Literary Canon in the Field of Tension Between Aesthetic and IdeologicalPrinciples

denominators or metaphors to characterise the literature of this period, most often referring either to the relations between culture and power, to the sharply perceived relativity of truth in a totalitarian society or to the national cultural resistance. Titles including the word "power" are quite common, especially in the articles and collections published during the 1990s, but metaphorical titles such as Nõukogude unelaadne elu (The Dream-like Soviet Life, Veskimägi 1996), Tõdede vankuval müüril (On the Shaking Wall of Truths, Olesk 2002 - a collection of articles), and Mälestus Golfi hoovusest (Memory of the Gulf Stream, Veidemann 1993) ${ }^{3}$ also characterise the general viewpoint that determines the conceptual grounds of these approaches. Therefore, especially in the 1990s but also later, the understanding of the recent literary past was noticeably influenced by the need for re-interpreting the experience of the past fifty years in the national and political context.

The rapid changes in the political and social sphere during the end of the 1980s and beginning of the 1990s gave rise to many processes in the literary discourse, including the introduction of new theories and terminologies, attempts to apply these theoretical terms and concepts to the Estonian literary history etc. The most difficult and, at the same time, one of the most delicate issues in the literary discussions of this period, is however, the discussion of the canon, the central question here being whether and what to do with the literary canon formed during - and at least partly by - the Soviet regime. This "problem of the canon" has at least three aspects which need to be considered when trying to describe the shaping of the national literary history. The first of these aspects concerns the Estonian Soviet-minded literature (works and authors representing collaboration or compromise with the regime). As postulated by Enn Soosaar in a discussion Estonian Literature in ESSR published at the beginning of 1992 the central question was whether "[...] we have the right to condemn writers and declare their works not necessary for our national literature if they have consciously or unconsciously, willingly or forcedly distorted and falsified the socio-political present or past of their own nation?" (Eesti kirjandus ENSV-s 1992: 117) There had indeed been many discussions, even quite radical declarations leading to public conflicts concerning the matter during 1991 and although the conflicts eased off after a while and there were, in fact, not many discussions on this topic during the following years, it is clear that a transition took place during the 1990s. The second aspect concerns the 'gaps' in the canon, the filling of which can be observed in more detail than the process of neglecting the literary works that most clearly served the Soviet

3 According to the foreword of this collection of articles, the metaphorical Gulf Stream refers to the national cultural resistance. 
UNT

ideology. This process started already at the end of the 1980s and involved introductions and studies of Estonian exile literature, some overviews of the underground magazines, and bringing the authors who had been in the so-called inner emigration (especially Uku Masing and Artur Alliksaar), into the canon. These first two aspects have also been described not so much as changing the canon but as restoring it (Hennoste 1997a: 69).

The third and most complicated aspect of these canon discussions can be illustrated through a seemingly minor episode amongst the quite heated discussions in 1991. A literary figure from the younger generation, Mait Raun, published an article declaring that the Estonian literature of the Soviet period was an ideologically engaged phenomenon and that this literature, especially as it became the mainstream during the 1960s, is not art but a social phenomenon which has its own great literary figures but which lacks great works. Raun stresses the need to fight for "pure art" and finds that for the "pure art" to win the former "great ones" have to fall (Raun 1991: 3). This article evoked a few sharp and emotional reactions, mostly blaming Raun for trivialising the literary heritage (e.g Reinla 1991, Veidemann 1991). This minor conflict could be considered just as a symptomatic episode of the time, not leaving marks on the canon, but as the following example shows, not all questions that Raun's declarations pose can be ignored.

Around the same time, another article was published in which Hasso Krull, one of the central cultural figures of the younger generation of literary critics and also one of the main introducers of Western theoretical thought, describes the literature of the 1970s and 1980s as "underwater literature" (Krull 1991: 1677). This term, mostly interpreted as a reference to the lack of air - the lack of contact with Western literatures - became widely cited and the concept was adopted by many critics. What was less discussed was Krull's argument that this kind of literature functions as the protector of humanist values and this role serves as the self-justification of this literature. As a potential opposite of this kind of literature, Krull describes the concept of "Literature of Enlightenment", a literature which has no justification and which can thus be "pure art" (Krull 1991: 1678-1679).

Although Raun's article offers more declarations than argumentation and of Krull's two concepts of literature mainly the first one drew wide attention, these texts indicate the tension between the aesthetic and the ideological dimension in the understanding of the status of the Soviet Estonian literature.

In addition to the function or status of literature the same tension appears in the way the linguistic code of the texts, the problem of freedom of expression and the relationship between the author and the reader is most often described. The latter has been characterised as a common system of secrets or codes 
The National Literary Canon in the Field of Tension Between Aesthetic and Ideological Principles

(Hennoste 1997b: 145; Pruul 2000: 177), the so-called Aesopian language as one of the keywords can also be noticed in many approaches (e.g Veidemann 2003: 165). It is clear that in the reception of literary works of the Soviet period the awareness of the context - whether it is the general context of censorship or the context of national identity and cultural resistance - plays an integral part. As Sirje Olesk has put it: "When Estonia was occupied, the nationalistic thinking was either visibly or secretly [...] the great narrative that underlay literature (especially poetry). All texts were read in this context even if the text themselves did not justify it." (Olesk 2002: 42) This argument can be illustrated through a dialogue between writer and literary critic Toomas Liiv and one of the central figures of the poetic revolution of the 1960s Paul-Eerik Rummo:

„T. L: [...] As an example of the Anti-Russian poetry of the 1960s I would name Paul-Eerik Rummo's narrative poem Väikese linna kohvikumuusikat (Some Café Music in a Small Town). When we analyse it at the Pedagogical Institute it always appears that we are dealing with an Anti-Russian (resp Anti-Soviet) text.

P.-E. R: To overcompensate and to show off I can say that about the same time I wrote this cycle I was also translating with mastery and free will Robert Rozhdestvenski's Requiem.

T. L: It is probably my mistake that I am leading this discussion in the wrong direction. However, Väikese linna kohvikumuusikat still seems to be an AntiRussian manifest in a way. There is, for example, an interesting motif of potato shoots which grow from the cellar up to the roof breaking apart the ceilings and incidentally cutting through the shopping nets (liberate the vegetables!). I realise this is awfully banal but at least two students have seen a stress on the need to liberate Estonia in these lines, a belief in the future of the Estonian nation ...

P.-E. R.: In my opinion this is ...

T. L: A profanisation?

P.-E. R.: The profanisation of the idea of freedom for Estonia in that case. Not that such an interpretation would be a profanisation of my beautiful poem but if potato shoots are taken to mean the fight for the freedom of Estonia, then this poem would profanise the fight for freedom." (Eesti kirjandus ENSV-s 1992: 124-125).

Do these references to the way the texts were read indicate that Mait Raun's and/or Hasso Krull's observations hold the key to the Estonian literary history? Does the 'national' in the Estonian national literary canon exclude the aesthetic principle? Should we consider the literature of the Soviet era as a social or ideological project or should the author's point of view be trusted rather than the reader's? The paradox here is that the same period, the 1960s, was 
UNT

the time when the literary process led to an aesthetic freedom: the ideological restrictions certainly remained, but relative aesthetic freedom was gained. Although there are at least three concepts of when and how the real 'revolution' in Estonian poetry took place - at the beginning of the 1960s through the earliest works of the 'Cassette Generation' (e.g Veidemann 1993); in second half of the 1960s through the more radical poetry of the 'Cassette Generation' and the poetry of the new debutants (Velsker 1999), or in the 1970s through the works of Jüri Üdi (Krull 1998) - and although the first breakthrough at the beginning of the 1960s can rather be viewed as the restoration of the tradition of the 1930s (Velsker 1999: 1213), those aesthetic processes formed the grounds for various phenomena affecting the poetics of literary works up until the present time. Also, when we look at the approaches to individual authors and their works, including the above-mentioned attempts to apply new theoretical concepts and terms to some of these texts, it is clear that the central focus is not only on the ideological dimension but also on various aesthetic phenomena. Moreover, the excerpt from the dialogue between Toomas Liiv and Paul-Eerik Rummo shows that the understanding of what and how some motifs or metaphors can be interpreted in the ideological context (at least in the sense of national cultural resistance) can be very different. Therefore, we should ignore neither the aesthetic principle nor the ideological, but it could also not be simply stated that these principles are intertwined - what they undoubtedly are and will remain so - without observing their dynamics in more detail. One sphere where this tension or dynamics occurs in its whole complexity is the teaching practice (which Toomas Liiv's example of the students' interpretations also indicates) as one cannot expect the students, even the students of literature at the university, to have the necessary package of references. The students are taught that they cannot always detect all semantic layers of the texts unless they consider the historical context, but it cannot be specified in all cases, when and how the context determines the interpretation. The following example should speak for itself - a poem by Hando Runnel ${ }^{4}$ published in 1970 in which a student sees a political reference (interpreting the spring motif as a reference to the Khrushchev thaw, the autumn as a reference to the frustration of the years after 1968):

4 Hando Runnel, a poet who made his debut in the middle of the 1960s and whose songlike poems were widely read throughout the 1970s, is indeed to a great extent an ideological poet; many of his works carry the concept of national cultural identity, but also various other motifs and ideas. 
The National Literary Canon in the Field of Tension Between Aesthetic and IdeologicalPrinciples

\author{
Kell kevadet lööb \\ Oues laguneb lumi \\ Jälle oitsevad kreegid \\ kodus akende all \\ ja õunapuu üksikus metsakurus \\ millest keegi ei tea ei keegi \\ Siis upub kõik üle pea rohtu \\ muistsed maanteed mälestuste tolmus \\ majad inimesed keda kunagi nähtud \\ Kerged võilille-ehmed õhus \\ äkki varisevad alla \\ algabki sügis \\ Suled silmad ja mõtled \\ millestki igavesest ${ }^{5}$ (Runnel 1970: 18)
}

In the context of teaching this problem of interpretation cannot be solved by stating that the ideological and aesthetic dimensions are intertwined, the overuse of the concept of Aesopian language as the key to interpreting literary texts of the Soviet period can be prevented only if the factors of the canon formation are studied in more detail thus bringing more detail into the canon itself.

Instead of a conclusion some possible approaches for this kind of canon studies could be pointed out. First, it is clear that further studies in the sphere of the history of reception, including the history of literary criticism as one of the central agents in the formation of the literary canon, are necessary in order to observe the ways the canon has formed and to ease the tension between the ideological and aesthetic dimension of the Estonian literature of the Soviet times. Secondly, these studies should not be isolated in the Estonian national literary canon: in order to increase the awareness of the dynamics between ideology and aesthetics in the canon formation, the studies should, at the same time, transcend the borders of the national canon.

Taking one more look at the literary discussions in the pivotal year of 1991 a thought by translator and literary critic Enn Soosaar deserves mention: in

5 The clock ticking spring / the snow is going / damsons again in full bloom / behind the windows of my home / and the apple tree in a lonely nook of woods / nobody knows about // Here everything drowning in grass / ancient roads in the dust / of memories houses people once seen / light dandelion tufts in the air / float suddenly down / and the autumn begins // Closing your eyes you think / of something eternal (Translated by Kersti Unt) 
UNT

an interview published in the cultural newspaper Sirp he points out the necessity of placing the national literature into a wider context, stating: "The more a process is viewed in isolation the more imposing it seems. Reading the publications of Estonian literary historians and critics often leaves the impression that Estonian literature has evolved and still evolves ex nihilo, by itself, apart from everything happening elsewhere." (Soosaar 1991: 3) It is not surprising that in the Soviet era the options of comparative studies were limited, the studies conducted since then have been notable, however, even now there are only a few works that attempt to contextualise the Soviet period of the Estonian literary canon by means of comparative study. One of the few examples, Tiit Hennoste's series of articles Hüpped modernismi poole. Eesti 20. sajandi kirjandusest Euroopa modernismi taustal (Leaps towards Modernism. About the Estonian Literature of the $20^{\text {th }}$ Century in the Context of European Modernism) published during the 1990s, shows the potential of such approaches. Returning to the notions of 'national', 'supra-national' and 'transnational' literary canon as Vanessa Matajc has described them, considering what was said above, we can conclude that there is not only a need for a transnational canon, but also a need for reviewing the national canons in the comparative context and especially for further comparative studies of the literatures that share similar historical experiences in the $20^{\text {th }}$ century even if not necessarily and not always a similar literary past.

\author{
Marja Unt \\ marja.unt@gmail.com \\ Tartu Ülikool \\ Kultuuriteaduste ja Kunstide Instituut \\ Ülikooli 16 \\ 51014 Tartu \\ EESTI
}

\title{
References
}

Eesti kirjandus ENSV-s 1992. - Looming. No. 1, 117-129.

Hennoste, T. 1997a. Kaanon. Kaanan. - Vikerkaar, 12, 60-70.

Hennoste, T. 1997b. Hüpped modernismi poole: Eesti 20. sajandi kirjandusest Euroopa modernismi taustal. 22. loeng. - Vikerkaar, 4-5, 144-154.

Hennoste, T. 2003. Kirjanduse periodiseerimisest. - Eurooplaseks saamine. Kõrvalkäija altkulmupilk. Artikleid ja arvamusi 1986-2003. Tartu: Tartu Ülikooli Kirjastus, 87-107. 
The National Literary Canon in the Field of Tension Between Aesthetic and Ideological Principles

Krull, H. 1991. Humanism ja valgustus: Murrang Eesti kirjandusideoloogias eelmisel kümnendil. - Akadeemia, 8, 1676-1683.

Krull, H. 1998. Jüri Üdi, Juhan Viiding ja eesti luule. - Juhan Viiding. Kogutud luuletused. Tallinn: Tuum, 585-615.

Matajc, V. 2010. The Trans-national Literary Canon and Shared Literary History between Supra-National and National Dimensions, Ideologies and Literariness. Interlitteraria, 15, I, 97-122.

Olesk, S. 2002. Tõdede vankuval müüril. Artikleid ajast ja luulest. Tartu: Eesti Kirjandusmuuseum.

Pruul, K. 2000. Vana sajandi uued luuletajad. - Varjatud ilus haigus. Valik sajandulõpu eesti luuletajaid. Tartu: EK\$, 175-207.

Raun, M. 1991. Millised rõivad on pühakul? - Sirp, 12.07, 3.

Reinla, A. 1991. Eesti kirjandus keskkütteahju? - Sirp, 19.07, 3.

Runnel. H. 1970. Avalikud laulud. Tallinn: Perioodika.

Soosaar, E. 1991. Eesti kirjandus ei ole rippumatu. - Sirp, 28.06, 3.

Veidemann, R. 1991. Müristage, poisid, kuid ärge labastuge - Sirp, 26.07, 5.

Veidemann, R. 2003. Mälestus Golfi hoovusest. Artikleid, esseid, pihtimusi 1986-1993. Tallinn: Perioodika.

Velsker, M. 1999. Mis on kuuekümnendad eesti kirjanduses? - Looming, 8, 1210-1216.

Veskimägi, K.-O. 1996. Nõukogude unelaadne elu. Tsensuur Eesti NSV-s ja tema peremehed. Tallinn. 